\title{
Customer Relationship Management and Customer Retention: Empirical Assessment from Nigeria's Insurance Industry
}

\author{
Samson Ifejionu Nwankwo and Sunday Stephen Ajemunigbohun* \\ Department of Accounting and Finance, Insurance Unit, Lagos State University, Nigeria
}

\begin{abstract}
Aims: The purpose of this study was to draw the attention of insurance practitioners in Nigeria to interrelationships that exist among CRM, customer retention and value creation. For this purpose, researchers have evaluated the relationship that exist between CRM and customer retention; and also ascertained if value creation was in any way extended to insuring populace in Nigeria.

Study design: The study employed cross-sectional survey design

Place and duration of study: Study was conducted in Lagos metropolis. Duration of study was from October, 2012 to February, 2013.

Methodology: The research was started with literature survey. The study employed stratified random sampling technique and thus, gathered data through the use of structured questionnaire. The sample population consisted of 58 respondents made up of marketing managers and underwriting managers drawn from 35 insurance companies which were randomly selected from the directory of member companies. The statistical instruments employed for this study were Simple linear regression and Kolmogorov-smirnov test. Two hypotheses were tested in this study.
\end{abstract}

Results: The study found that CRM positively influences customer retention in the Nigeria's Insurance Industry, and thus helps create values for insuring populace in Nigeria.

Conclusion: The study evidenced interlink between various constructs understudied.

Keywords: Customer relationship management; Customer retention; Value creation; Insurance industry; Assessment; Nigeria

\section{Introduction}

The restructuring exercises done, overtime, in the insurance subsector of the Nigeria's economy had made the industry so dynamic despite the lingering market forces peculiar to the Nigeria's business environment such as change in consumer taste, technological change, demographic variation, political and economic instability and the likes. All these forces had been described as drivers of globalization [1]. There is need for practitioners of insurance in Nigeria to continually look in the way of relationship management of their customers, retaining those they are able to convince, acquire and satisfy profitably and then create values that meet up with the vision, mission and integrity of their organization and most of all, expectations of their numerous customers. According to Pop and Petrecsu [2], success will usually flow towards viable financially-sound companies who understand how to get and keep their client's trust employing flexible pricing policies, diversified products and excellent customer service.

Insurance industries in most emerging markets are characterized by poor perception, low level of technology leverage, low investment and asset management capabilities, and poor regulatory framework [3]. However, the Nigeria's insurance industry has demonstrated the ability to survive in the face of enormous challenges. Previous studies of experts in the field of insurance in Nigeria had thus criticized the industry for poor image [4,5]; lack of trust and poor communication system [6-8]; low patronage [9]; dearth of human capital and professional skills [10]; low market penetration [11]; gross under-utilization of capital [12]; yet the industry is about the highest capitalized in Africa [13].

Nigeria, according to 2006 census, has been reported to an estimated population of 140 million people with an estimated non-life \& life insurance income receipt of $\$ 787$ million and $\$ 147$ million respectively in 2009; and low level of insurance penetration of mere $0.6 \%$ [14]. This sector was said to recorded a significant progress with the successful recapitalization in 2007 which brought the industry capacity to 49 with a premium income written little above 200 billion in a country of over 160 million people as against an industry shareholders' funds of about N 347 billion [12]. It has therefore shown that the Nigerian insurance sector is supported by obvious demographic advantages and Nigeria's economic growth prospects, relative to other emerging markets. However, the contraction in the number of companies (down from 104 in 2006, prior to the consolidation in the industry) has brought about improved capacity even in the ability of these companies to settle larger claims.

More so, Nigeria's insurance market is dominated by non-life segment, driven by mandatory third-party motor insurance. The growth in motor insurance premium (especially third party policies) has also been fueled by the speedily emerging middle class in Nigeria as private cars are fast becoming a necessity rather than luxury [13]. NAICOM, in 2008, came up with the introduction of the Market Development and Restructuring Initiative (MDRI), a medium term reform plan intended to cover from 2009 to 2012, aimed at improving

*Corresponding author: Sunday Stephen Ajemunigbohun, Insurance Unit, Department of Accounting and Finance, Lagos State University, P.M.B. 0001, LASU Post Office, Ojo, Lagos, Nigeria, Tel: +234-705-534-2854; E-mail: insurancelecturerlasu2009@yahoo.com

Received July 16, 2013; Accepted October 01, 2013; Published October 08, 2013

Citation: Nwankwo SI, Ajemunigbohun SS (2013) Customer Relationship Management and Customer Retention: Empirical Assessment from Nigeria's Insurance Industry. Bus Eco J 4: 081. doi: 10.4172/2151-6219.1000081

Copyright: (c) 2013 Nwankwo SI, et al. This is an open-access article distributed under the terms of the Creative Commons Attribution License, which permits unrestricted use, distribution, and reproduction in any medium, provided the original author and source are credited. 
capacity of the industry, market efficiency and protection of consumers in the country. The principal target of the reform plan is to implement mandatory insurance covering six areas, which include, Motor Third Party insurance, Employers Liability insurance, Occupiers Liability insurance, Group Life insurance Buildings under construction, Healthcare Professional and Indemnity insurance. Also, compulsory insurance is being a primary tool for enhancing the penetration rate in the industry.

Customer relationship management (CRM) is being one of the leading modern business and market strategy employed in high competing business environment. More so, understanding the changing needs and expectations of customers and ensuring retention of such customers should primarily be the concern of business managers. Understanding customers' profitability and retaining profitable customers had been recognized as one of the core value of customer relationship management [15]. Therefore, maximizing profitability of the total customer relationship over a period of time tends to ensure increased profit for any organization as many companies had tapped into the use, measure and reliability of customer value in their activities $[16,17]$; because customer value is a key element of CRM performance measure [18]. The study is aimed at ascertaining relationship that subsist between CRM and customer retention and thus, finds out if CRM helps create values for insuring populace in Nigeria. This paper is divided into five sections. Having concluded with the introductory aspect above, the rest of the paper is structured in the following regards: theoretical and empirical framework, methodology, results and discussion, and conclusion.

\section{Theoretical and empirical framework}

Many studies in the past have shown interrelationship among Customer Relationship Management (CRM), customer retention and value creation. However, this study further investigates the relationships and usefulness of these constructs with its assessment from the Nigeria's insurance market. To mention few, previous studies had interlinked constructs under study with insurance industry [19-22]. It is worthy to note that CRM has been described in a number of ways; and it means different things to different caliber of people depending on the working arena it's being used in [23]. Importantly, CRM has been noted to be the most viable means to promote the development and expansion of customers' base which, consequently, will assist the enhancement of profitability and invite loyalty [24-26].

Customer relationship management $(\mathrm{CRM})$ is a philosophy within the managerial arena that seeks to create lasting relationship with customer. CRM is being described as a strategic method which is concerned with creating enhanced shareholder value via the evolvement of suitable alignments with key customers and customer segments [27]. According to Richards and Jones [28], CRM is a set of business activities supported by the alignment of both technology and process directed by strategy and designed to enhance firm performance in an area of customer management. Thus, successful customer relationship management aims at fathoming the desires and needs of the customers and is accomplished by the integration of these desires with the organization's strategy, technology, people and enterprise process [21].

The study of Al-Khouri [29] suggested key common components of CRM framework. The dimensions of which are: key customers focus, knowledge management, CRM organizations, and technologybased CRM [30-32]. However, previous studies had also shown that CRM improves financial efficiency of marketing effort and pricing
[33,34]; improves product differentiation, customer commitment, satisfaction and loyalty [35,36]; enhances long-term profitability [37]; enables knowledge management [38]; enhances customer acquisition, development, retention and decision making [39,40]; and brings about increased firm performance $[32,41,42]$.

A report has shown that many insurers have not completely harness their customer data and optimize customer relationships [43]. To enforce a strategy towards customer management, insurers have to be ready to invest in modern technology to assist them: understand the customer and their behaviour; put customers to identify groups with similarities that can be aimed jointly; assign values to segmented customer, predict behaviour of customers and implement techniques that accomplish satisfaction and retention of customers; and identify and maximize cross-sell and up-sell opportunities to increase sales. Most insurance companies are set up for new customer acquisition. However, recent study argued that customer retention plays a bigger role in profitability [44]. According to the Database Marketing Institute, every $\$ 1$ paid toward customer retention escalates profits more than every $\$ 5$ spent on acquiring new customer.

Customer retention is extremely vital for business to remain competitive. It has recently become more significant compared to customer acquisition. According to research conducted by Maxham [45], customer retention had been measured by four dimensions, that is, overall firm satisfaction; positive words of mouth; repeat purchase intentions; and loyalty to the firm. In a recent study by Lin and Wu [46], it has been proved that there exists a statistically significant relationship between quality commitment, trust and satisfaction and customer retention and future use of product. In an earlier study, it has been found that trust and commitment lead directly to cooperative behaviour that are conducive to relationship marketing success; and important in the establishment and maintenance of long term relationships with customers [22].

Customer retention is the strategic objective of striving to maintain long term relationships with customers. Customer retention is the mirror image of customer defection. A high retention rate is equivalent to a low defection rate. However, customer retention is not a new concept among insurers, but today's market demands a novel approach to building and maintaining loyalty. An effective Customer Retention (CR) strategy not only retains the customer but promotes the sales of additional products to that customer as needs arise. Four proactive elements as suggested by Navigant financial services are at the core of a successful program [47]. These are: target $\&$ tailor (get to know your client's behaviours and priorities); enhance customer experience (align deliverables with customer requirements); embed retention (integrate retention in the organization's customer service policies); and engage employees (instill in employees that sense that they own the client relationship). A practical study in UAE has shown that $46 \%$ of those who changed providers feel that their former insurer did not make any effort to prevent them from switching. Data also show that $56 \%$ of respondents in the UAE believe that insurance companies do not adequately reward loyalty [48].

Some studies in the past had identified the benefits that customer retention delivers to an organization and thus, noted that the longer a customer stays with an organization, the more satisfaction than seeking new customers $[49,50]$. In recent study, many factors had been noted to affect the loyalty of customers and the period that customers remain with the organization; amongst these factors are: higher initial costs of finding and attracting new customers, positive word of mouth promotion, increases in both the value and number of purchases, the 
customer concrete understanding of the organization, to mention few [51].

Creating customer value creation has been a vital source of competitive advantage. However, the process of value creation is a key component of CRM as it transforms firm and customer strategies into specific statements of what value is to render to customers, and consequently what value is to render to the supplier organization. The value creation process has three essential components [52], which are: ascertaining what value the company can render to its customers (the 'value customer receives'); ascertaining the value the organization gets from its customers (the 'value organization receives); and maximizing the lifetime value of desirable customer segments. To the customers, the concern is value proposition and assessment; while the concern is economics of customer acquisition and retention to the organization.

Value is the customer's estimate of the extent to which a product or service can satisfy their needs. It is also the worth of a specific action or object relative to an individual's needs at a particular time [53]. However, there are normally costs associated with the derivation of benefits such that a general model of value would identify the worth of the worth of the benefits received for the price paid [54]. Therefore, value is relative to customer expectations and experience of competitive offerings within a category and can be derived from sources other than products, such as the relationships between buyers and sellers [55]. With the study of Ryssel et al. [56], trust has been recognized as having a vital impact value creation and concludes that value creation is a function of the atmosphere of a relationship rather than the technology employed.

While the creation of customer value is being based on three principles, which are: (i) customers will choose between alternative offerings and select the one that (they perceive) will offer them the best value, (ii) customers do not want product or service features, they want their needs met, (iii) it is more profitable to have a lasting relationship between a customer and a company rather than a one-off transaction; creation of value was argued to be dependent upon firm's ability to render high performance on the benefits that are crucial to the customer and this in turn is rooted in their technological competence and business process, or core competences $[57,58]$.

\section{Methodology}

The research design employed in this study was a cross-sectional survey design. The use of survey design is justified because it has its advantages of predicting behavior [59]; and thus, identifying attributes of a large population from a small group of individuals, the economy of the design and the rapid approach in collection of data $[60,61]$. The data were collected through the survey among insurance companies in Nigeria. The major instrument employed in gathering data was a structured questionnaire. The use of structured questionnaire was because of its appropriateness to survey research [62]. The questionnaire consisted of two parts, part A and B. While part A consisted of personal data of respondents, part B contained statement related to constructs understudied. Respondents' view of the issues under study was assisted via the completion of the questionnaire which was drawn using a Likert-type scaling measurement of 'Agree', 'Indifferent' and 'Not agree'.

Among 62 members of the Nigeria's insurance companies operating presently in Nigeria, consisting of 34 specialist general insurance companies, 18 specialist life insurance companies, 08 composite insurance companies and 02 reinsurance companies [63]; 35 companies were chosen at random according to their rank in order of gross premium and market share capabilities (that is, top 35 member companies as document by the Nigerian Insurers Association), giving a $57 \%$ of the industry capacity. The sample population, therefore, was drawn from Lagos, the commercial base of Nigeria, which houses the largest number of insurance companies in Nigeria. A total of 70 copies of the questionnaire were sent. 2 copies of the questionnaire (meant for Marketing manager and Underwriting manager, respectively) accompanied by a covering letter. The choice of the sampling units was informed by the peculiarity of the technical nature of insurance services in Nigeria. To ensure the genuiness of responses, regular telephone calls and visits were options in order for clarification purposes and to facilitate prompt filling, handling and returning of the questionnaire. Eventually, among 66 copies retrieved, 58 were correctly completed and these were analyzed for this research (that is, a $83 \%$ effective response rate).

On the reliability and validity of the study, a pilot study was thus carried out to test the reliability of measures. The Cronbach alpha on questionnaire administration is 0.801 ; which shows that the alpha level is above the required 0.70 . On the validity of the study, both theoretical and content validity were explored. The theoretical validity was sought for by developing the measures of the constructs under study from well-grounded and extant literature from other previous studies. The content validity was established by giving a set of the draft questionnaire to few selected insurance companies' executives and members of the academia in the field of management and insurance. These experts went through the items on the instrument and made necessary suggestions which enable the researchers to present the items within the linguistic understanding of the respondents.

\section{Test of hypotheses}

The researchers formulated 2 hypotheses that serve to provide a clear direction for the conduct of this research and these were tested. A hypothesis test is a statistical method that uses sample data to evaluate a hypothesis about a population parameter [64]. The hypotheses testing techniques used were simple regression for testing hypothesis 1 and kolmogorov-smirnov test for testing hypothesis 2. A linear regression is simple if it involves only two variables $\mathrm{Y}$ (dependent variable) and only one independent variable $\mathrm{X}$, where $\mathrm{Y}=\mathrm{f}(\mathrm{X})$ and where $\mathrm{Y}=$ customer retention, $\mathrm{X}=\mathrm{CRM}$.

The simple regression establishes whether or not any relationships exist between the two variables Y and X [65]. The Statistical Package for Social Sciences (SPSS) aided the test of hypothesis 1 . The KolmogorovSmirnov test is appropriate because it is a non parametric tool used to test the goodness of fit of an ordinal data and calls for a comparison of an observed sample distribution with a theoretical distribution [66]. The test focuses on the largest value of the deviation among observed and theoretical proportions. The kolmogorov-smirnov is given as:

\section{$\mathrm{D}=\max \left|\mathrm{F}_{\mathrm{o}}(\mathrm{X})-\mathrm{S}_{\mathrm{n}}(\mathrm{X})\right|$}

Where $\mathrm{F}$ is the number of observations; $\mathrm{F}_{0}(\mathrm{X})$ is the specified (or theoretical) cumulative frequency distribution under Ho for any value of $\mathrm{X}$ and is the proportion of cases expected to have scores equal to or less than $\mathrm{X} ; \mathrm{S}_{\mathrm{n}}(\mathrm{X})$ is the observed cumulative frequency distribution of a random sample of $\mathrm{N}$ observation for any value of $\mathrm{X}$.

The procedure is as follows: specify the null hypothesis; specify the level of significance; and state the decision rule. The degree of freedom is measured at $5 \%$ level of significance. The critical value of $D$ for sample size of $\mathrm{N}>35$ (i.e. large samples). The decision rule is that null hypothesis $\left(\mathrm{H}_{\mathrm{o}}\right)$ will be rejected if the calculated $\mathrm{D}\left(\mathrm{D}_{\text {cal }}\right)$ is greater than 
the tabulated $\mathrm{D}\left(\mathrm{D}_{\mathrm{tab}}\right)$ under the deviation level of $5 \%$. The tabulated $\mathrm{D}$ from the kolmogorov-smirnov test table is usually represented by $(\alpha / \sqrt{ } N)$; where $\alpha=1.36$ and $N=$ number of observation.

$\mathrm{H}_{1}$ : Customer relationship management $(\mathrm{CRM})$ has significant relationship with customer retention in Nigeria's insurance companies

$\mathrm{H}_{2}$ : Customer relationship management (CRM) does help create values for insuring public in Nigeria

While the $\mathrm{H}_{\mathrm{o}}$ represents the null hypothesis, the $\mathrm{H}_{\mathrm{i}}$ represents the alternative hypothesis. The null hypothesis is set up to be the logical counterpart of the alternative hypothesis such that if the null hypothesis is false, the alternative hypothesis must be true [67].

\section{Results and Discussion}

\section{Personal details of respondents}

The demographic characteristics of the respondents covered are sex, age, highest educational qualification and length of time with the organization. The information detailed in Table 1 reveals that male respondents consist $55.2 \%$, and female respondents $44.8 \%$. Also from Table 1, respondents with bachelor's degree or its equivalent ranked highest with $53.5 \%$, followed by Master's degree, others and $\mathrm{PhD}$ holders with $31 \%, 12.1 \%$ and $3.4 \%$ respectively. This shows that respondents are knowledgeable and well trained enough to understand the concepts of CRM, customer retention and value creation. The respondents who have length of experience with the organization for ten but less than fifteen years are in the majority (39.7\%), followed by those that have worked for five but less than ten years. The third ranked are those who have one but less than five work experience. The implication of this is that most of the respondents have had a reasonable length of work experience which explains their practical experiences of customers' action or inactions of these various constructs. The simple frequency percentage statistical instrument was employed in explaining the personal details of respondents (Tables 1-4).

\begin{tabular}{|l|c|c|}
\hline \multicolumn{1}{|c|}{ Sex of the Respondents } & No. & $\%$ \\
\hline Male & 32 & 55.2 \\
\hline Female & 26 & 44.8 \\
\hline Higesht Qualification & 31 & 53.5 \\
\hline Bachelor's degree or its equivalent & 18 & 31.0 \\
\hline Master's degree & 02 & 3.4 \\
\hline PhD & 07 & 12.1 \\
\hline Others & \multicolumn{2}{|l|}{} \\
\hline Length of time with the organization & 11 & 18.9 \\
\hline Less than one year & 08 & 13.8 \\
\hline One but less than five years & 13 & 22.4 \\
\hline Five but less than ten years & 23 & 39.7 \\
\hline Ten but less than fifteen years & 03 & 5.2 \\
\hline Fifteen years beyond &
\end{tabular}

Table 1: Personal Details of the Respondents (Source: Survey report, 2012-2013)

\begin{tabular}{|c|c|}
\hline & Responses (\%) \\
\hline \multicolumn{2}{|l|}{ CRM } \\
\hline Agree & $43(74.1)$ \\
\hline Indifferent & $13(22.4)$ \\
\hline Not agree & $02(3.5)$ \\
\hline \multicolumn{2}{|c|}{ Customer retention } \\
\hline Agree & $50(86.2)$ \\
\hline Indifferent & $08(13.8)$ \\
\hline Not agree & $00(0.0)$ \\
\hline
\end{tabular}

Table 2: Responses to the testing of hypothesis 1 (Source: Survey report, 20122013).

\begin{tabular}{|c|c|}
\hline Linear R & 0.728 \\
\hline R Square & 0.531 \\
\hline Adjusted R square & 0.512 \\
\hline Standard Error & 0.2101 \\
\hline
\end{tabular}

Table 3: A simple linear regression analysis of contribution of independent variable to the dependent variable.

\begin{tabular}{|c|c|c|c|c|}
\hline & DF & Sum of Square & Mean Square & F-ratio \\
\hline Regression & 1 & 3.659 & 3.659 & \\
\hline Residual & & 56 & 3.238 & 0.058 \\
\hline
\end{tabular}

Table 4: Analysis of Variance Table.

Hypothesis 1: Table 3 indicates that the independent variable (CRM) yielded a coefficient of linear regression $\left(\mathrm{R}^{2}\right)$ of 0.531 accounting for $53.1 \%$ of the variance that portrays the relationship between CRM and customer retention in Nigeria's insurance industry. The table also shows that the analysis of variance for the simple linear regression data produced F-ratio value of 63.27 which significant at 0.05 . The result from hypothesis 1 shows a positive significant relationship between CRM and customer retention. This, therefore, confirms the earlier studies who noted that customer focused service is an important component which has assisted facilitated mutual relationship between organizations and their various customers $[68,69]$. This result, again, concurs with those who earlier postulated that a variety of CRM activities can work together to enhance customer retention [70] (Table 5).

Hypothesis 2: CRM does not help create value for insuring public in Nigeria. From the Kolmogorov-Smirnov frequency table for the hypothesis, the calculated $\mathrm{D}$ value is the point of greatest divergence between the cumulative observed and cumulative theoretical distribution, which is 0.2701 . The tabulated $\mathrm{D}$ from the KolmogorovSmirnov test table at $(\alpha / \sqrt{ } \mathrm{N}=1.36 \sqrt{58})$ is given as:

$$
\mathrm{D}=\alpha / \sqrt{\mathrm{N}}=1.36 / \sqrt{ } 58=0.1785
$$

In this case, since calculated $\mathrm{D}$ value (0.2701) exceeds the critical value of 0.1785 , the null hypothesis (Ho) stating that CRM does not help create values for Insuring public in Nigeria is rejected at $\alpha=0.05$ (Table 5). This, then, indicates that CRM does help create values for Insuring public in Nigeria. This result confirms the earlier study of [71] who posited that proactive customer business development and building partnership relationship with the most important customers will eventually leads to superior mutual value creation between the organization and their customers. Also, in support of this result, the study of Fagbemi and Olowokudejo [21] had empirically evidenced customers responses on the extent to which insurance organizations use the CRM strategies in value creation to their customers in Nigeria.

\section{Conclusion}

This study attempts to find out the interrelationships that subsist among CRM, customer retention and value creation with the Nigeria's insurance industry as a research ground for its empirical assessment. While the study proves a significant and indeed a positive relationship that exist between CRM and customer retention; it was also discovered from the surveyed respondents that CRM, indeed, creates values to the insuring public in Nigeria. In the study of Kotler and Armstrong [72], it has been stated that the goal of any organization should go beyond attracting new customers and creating transactions but should also include retaining existing customers. It has been noted that a long-term relationship leads to lower relationship costs and higher profits; and 


\begin{tabular}{|c|c|c|c|}
\hline Rank of view of respondents Hypothesis & Agree & Indifferent & Not agree \\
\hline $\mathrm{F}=$ Number of respondents according to their views that CRM does not help create values for Insuring public in Nigeria & 06 & 17 & 35 \\
\hline $\mathrm{F}_{0}(\mathrm{X})=$ Theoretical cumulative distribution of choices under Ho & 0.3333 & 0.6666 & 1 \\
\hline$S_{n}(X)=$ Cumulative distribution of observed choices & 0.1034 & 0.3965 & 1 \\
\hline$\left|F_{0}(X)-S n(X)\right|$ & 0.2299 & 0.2701 & 0 \\
\hline
\end{tabular}

Table 5: Kolmogorov-Smirnov frequency table for Hypothesis 2 (Source: Survey report, 2012-2013).

earlier research works had proven that customers who are loyal not only improve an organization's profit but also strengthen its competitiveness [73-75].

Customer value is being noted to depend on how the customer perceived the benefits of an offerings and the sacrifice that is associated with its purchase [76]. Therefore, companies need a set of morally and legally defensible values to guide their actions and to shape their dealings with both employees and customers. To this extent possible, insurance companies should clarify their firm's value and expectations in dealing with prospective and existing customers, as well as making effort to attract and retain customers who share and appreciate these identical values.

\section{Recommendation, contribution to knowledge and limitations of the study}

On recommendation, captains of the industry should stand up to the challenge of ensuring that insurance companies in Nigeria keep records of their customers and identifying the key ones and making effort to tailor products to meet customers' needs, desires and expectations. Secondly, the various touch points of insurance customers (that is, request for insurance coverage, filling of proposal forms, complaint lodgment, renewal of policies, claims request and the likes) should be genuinely and adequately attended to. Lastly, regular deployment and encouragement of IT facilities be used as means of maintaining and managing customers' relationship, retention and value creation.

This study contributes significantly to knowledge in that it educates insurance companies' managers of need to continually evaluate their firm's relationship management to customers and the need to integrate customer retention and value creation into their vision and mission statement. It also informs regulatory authorities of the need to continually review the customer database of insurance companies.

There are some notable limitations to this study. First, data were gathered from insurance practitioners (specifically marketing and underwriting officers) only and the views of the insuring populace were not considered. Secondly, the research was unable to evidence the database of the customers of surveyed companies. Lastly, future research can endeavour to investigate reasons why insurance companies find it almost impossible often time to retain a policyholder for longer period.

\section{Competing Interests}

The authors declare that they have no competing interests.

\section{Author's Contribution}

This work was carried out in collaboration between both authors. Author SIN designed the study and prepared the introduction. Author SSA reviewed the literature, gathered all the data, carried out the final estimations, statistical analysis and drafted the final manuscript. Author SIN edited the final draft.

\section{References}

1. Czinkota MR, Ronkainen IA, Moffett MH (2009) Fundamental of international business. (2nd edn), Wassex, New York.

2. Pop NA, Petrecsu E (2009) Particularities of the marketing activity in the insurance industry. The Journal of the Faculty of Economics-Economic 4: 788-792.

3. Ahmad A, Zalina S (2008) An assessment on service quality in Malaysia insurance industry. Communcation of the IBIMA 1: 13-26.

4. Gbede GO (2003) Marketing insurance service. Lagos, Westbourne Business School.

5. Obasi N (2007) Modern insurance business management. Lagos: Nigerian Insurers Association.

6. Olowokudejo FF (2009) Does religion affect the procurement of insurance policies? Evidence from Nigeria. The Nigerian Journal of Risk and Insurance 6: $30-42$.

7. Yusuf TO, Gbadamosi A, Hamadu D (2009) Attitude of Nigerians towards insurance services: an empirical study. African Journal of Accounting, Economics, Finance and Banking Research 4: 34-46.

8. Ojikutu RK, Yusuf TO, Obalola MA (2011) Attitude and perception about insurance fraud in Lagos State, Nigeria. European Journal of Scientific Research 57: 615-625.

9. Ajemunigbohun SS (2009) An assessment of marketing communication mix elements on the demand for insurance products: a case of selected insurance companies in Lagos State. Dissertation submitted for the award of M.Sc Business Administration (Marketing), Faculty of Business Administration, University of Lagos, Akoka.

10. Babington-Ashaye F (2009) Re-engineering the insurance industry. Risk Analyst Insurance Brokers Limited.

11. Nwankwo SI, Durowoju ST (2010) Customers' evaluation of the quality of insurance service in Lagos, Nigeria. International Journal of Business and Management 6: 265-272.

12. Onuoha R (2012) Nigeria at 52: insurers' capital utilization still low.

13. Nigerian insurance sector report- Trotting at the pace of reforms (2011) Lagos: AfrInvest.

14. Staib D, Louis B (2010) World insurance in 2009: Premium dipped, but industry capital improved. Swiss Re Publication, Switzerland.

15. Hawkes VA (2000) The heart of the matter: the challenge of customer lifetime value. CRM Forum Resource.

16. Rosset S, Neumann E, Eick U, Vatnik N, Idan Y (2002) Customer lifetime value modeling and its use for customer retention planning. Proceedings of ACM SIGKDD International Conference on Knowledge Discovery and Data Minning 332-340.

17. Kim S, Jung T, Suh E, Hwang $H$ (2006) Customer segmentation and strategy development based on customer lifetime value: a case study. Expert System with Application 31: 101-107.

18. Samsudin W, Mohd KA, Mazlan AM, Ariff AM, Abdul Halim AG (2012) Influence of customer value on customer relationship management performance: views of credit card user in Malaysia. Business and Management Review 2: 1-8.

19. Insurance customer retention and growth: leveraging business analytics to retain existing customers and cross-sell and up-sell insurance policies (2010) IBM Software Group.

20. Oghojafor BEA, Aduloju SA, Olowokudejo FF (2011) Information technology and customer relationship management (CRM) in some selected insurance firms in Nigeria. Journal of Economics and International Finance 3: 452-461.

21. Fagbemi AO, Olowokudejo FF (2011)A comparison of the customer relationship management strategies of Nigerian banks and insurance companies. International Journal of Management and Business Research 1: 161-170.

22. Robert-Lombard M, Du Plessis L (2012) Customer relationship management (CRM) in a South African service environment: an exploratory study. African Journal of Marketing Management 4: 152-165. 
Citation: Nwankwo SI, Ajemunigbohun SS (2013) Customer Relationship Management and Customer Retention: Empirical Assessment from Nigeria's Insurance Industry. Bus Eco J 4: 081. doi: 10.4172/2151-6219.1000081

23. Dimitriadis S, Stevens E (2008) Integrated customer relationship management for service activities: an internal/external gap model. Managing Service Quality 18: $496-511$

24. Piskar F, Faganel A (2009) A successful CRM implementation project in a service company: case study. Journal of Management, Informatics and Human Resources 42: 199-208.

25. Mylonakis J (2009) Customer relationship management functions: a survey of Greek bank customer satisfaction perceptions. The IUP Journal of Bank Management 8: 7-31.

26. Wu S, Li P (2011) The relationship between CRM, RQ and CLV based different hotel preferences. International Journal of Hospitality Management 30: 262-271.

27. Payne A, Frow P (2005) A strategic framework for customer relationship management. Journal of Marketing 69: 167-176.

28. Richards KA, Jones E (2006) Customer relationship Management: finding value drivers. Industrial Marketing Management 37: 120-130.

29. Al-Khouri AM (2012) Customer relationship management: proposed framework from a government perspective. Journal of Management and Strategy 3: 34-54

30. Abdullateef AO, Moktar SS, Yusoff RZ (2010) The impact of CRM dimensions on call center performance. International Journal of Computer Science and Network Security 10: 184-195.

31. Akroush NM, Dahiyat ES, Gharibeh SH, Abu-Lail NB (2011) Custome relationship management implementation: an investigation of a scale's generalizability and its relationship with business performance in a developing country context. International Journal of commerce and Management 21: 158-190.

32. Abdul AM, Basri BR (2012) Customer relationship management (CRM) in hote industry: a framework proposal on the relationship among CRM dimensions, marketing capabilities and hotel performance. International Review of Management and Marketing 2: 220-230.

33. Sheth JN, Sharma A (2001) Efficacy of financial measures of marketing: it depends on markets and marketing strategies. Journal of Targeting, Measurement and Analysis for Marketing 9: 341-356

34. Jones E, Sundaram S, Chin W (2002) Factors leading to sales force automation use: a longitudinal analysis. Journal of Personal Selling and Sales Management 22: $145-156$.

35. Park C, Kim Y (2003) A framework of dynamics CRM: linking marketing with information strategy. Business Process Management Journal 9: 652-671.

36. Verhoef PC (2003) Understanding the effect of customer relationship management efforts on customer retention and customer share development. Journal of Marketing 67: 30-45.

37. Zikmund WG, McLead R, Gibert FW (2003) Customer relationship management integrating marketing strategy and information technology. Hoboken $\mathrm{NJ}$ : John Wiley \& Sons.

38. Leigh TW, Tanner JF (2004) Introduction: JPSSM Special issue on customer relationship management. Journal of Personal Selling and Sales Management 24: $259-262$

39. Tanner JF, Ahearne M, Leigh TW, Mason CH, Moncrief W (2005) CRM in sales intensive organizations: a review and future direction. Journal of Personal Selling and Sales Management 25: 171-182

40. Spekman RE, Carraway R (2006) Making the transition to collaborative buyerseller relationships: an emerging framework. Industrial Marketing Management 35: $10-19$

41. Read B (2009) Top tips to build and keep customer loyalty with CRM. Customer Interactive Solution 27: $26-28$

42. Botha G, Van Rensburg AC (2010) Proposed business process improvement model with integrated customer experience management. South African Journal of Industrial Engineering 2: 45-47.

43. Capgemini (2007) Customer optimization: the benefits of building an effective customer management strategy. World Insurance Report

44. McLauchlin J (2010) Retaining customers: it's not just about the renewal. LIMRA'S The Marketer Newsletter 17: 1-3.

45. Maxham JG (2000) The service recovery's influence on customers' satisfaction positive word of mouth and purchase intentions. Journal of Business Research 54: 11-24.
46. Lin JSC, Wu CY (2011) The role of expected future use in relationship-based service retention. Managing Service Quality 21: 535-551.

47. Navigant Financial Services (2010) Using best-in-class customer service to improve customer retention.

48. Global Consumer Insurance Survey (2012) Voice of the customer time for insurers to rethink their relationship.

49. Reichheld FF, Kenny D (1990) The hidden advantages of customer retention Journal of Retail Banking 7: 19-23.

50. Abratt R, Russel J (1999) Relationship marketing in private banking in South Africa. International Journal of Bank Markeing 17: 5-19.

51. Ghazizadeh M, Besheli AS, Talebi V (2010) Assessing of bank customers retention and loyalty: a case study of state-owned banks in Tehran. European Journal of Social Sciences 17: 274

52. Payne A. The value creation process in customer relationship management.

53. Lovelock C, Wright $L$ (1998) Principles of service marketing and management (2nd edn), Prentice Hall.

54. Anderson JC, Narus JA (1998) Business marketing: understand what customers value. Harv Bus Rev 76: 53-65.

55. Simpson PM, Sigauw JA, Baker TL (2001) A model of value creation: supplier behaviours and their impact on reseller perceived value. Industrial Marketing Management 30: 119-134.

56. Ryssel R, Ritter T, Gemunden HG (2004) The impact of information technology deployment on trust, commitment and value creation in business relationship. Journal of Business and Industrial Marketing 19: 197-207.

57. Doyle $P(2000)$ Value based marketing. Wiley.

58. Kothandaraman P, Wilson D (2001) The future of competition: value creating networks. Industrial Marketing Management 30: 379-389.

59. Bordens SK, Abott BB (2002) Research design and methods: processes approach. (5th edn), McGraw-Hill, New York.

60. Fowler FJ (1995) Improving survey questions: design and evaluation. SAGE

61. Babbie E (1990) Survey research method. (2nd edn), Wadsworth Pub Co.

62. Babbie E. The basic of social research. (3rd edn), Thomson Learning Inc, Canada.

63. Nigerian Insurers Association (2011) Nigeria insurance report.

64. Gravetter FJ, Wallnau LB (2000) Statistics for the behavioural sciences. (5th edn), Thomson Wadsworth.

65. Kasumu RB (2000) A basic course in statistics. (1st edn), Fatol Venture, Lagos.

66. Cooper DR, Schindler PS (2005) Business research methods. (9th edn), McGraw-Hill, New York.

67. Pagano PR (1994) Understanding statistics in the behavioural sciences. (4th edn), West Publishing Company, USA.

68. Gan C, Cohen D, Clemes M, Chong E (2006) A survey of customer retention in the New Zealand banking industry: banks and bank systems. Journal of Business Research 1: 83-99.

69. Varki S, Colgate M (2005) The role of price perceptions in an integrated mode of behavior intentions. Journal of Service Research 3: 232-240.

70. Pfeifer PE, Farris PW (2004) The elasticity of customer value to retention: the duration of a customer relationship. Journal of Interactive Marketing 18: 20-31.

71. Chaitanya KV (2005) Metamorphosis of marketing financial services in India. Journal of Services Research 5: 155.

72. Kotler P, Armstrong G (2008) Principles of marketing. (12th edn), McGraw-Hill, New York.

73. Day G (2008) Managing market relationships. Journal of the Academy of marketing science. 28: 24-30.

74. Reinartz WJ, Kumar V (2002) The mismanagement of customer loyalty. Harvard Business Review.

75. Fill C (2005) Marketing communication: engagement, strategies and practices (4th edn), Pearson Education Limited, England.

76. Jobber D (2007) Principles and practice of marketing. (5th edn), McGraw-Hill Education, Berkshire. 